\title{
Detection of Mycosphaerella graminicola in Wheat Leaves by a Microsatellite Dinucleotide Specific-Primer
}

\author{
Kamel Abd-Elsalam ${ }^{1,2,3, *}$, Ali H. Bahkali ${ }^{2}$, Mohamed Moslem ${ }^{2}$, Pierre J. G. M. De Wit ${ }^{2,4}$ and \\ Joseph-Alexander Verreet ${ }^{1}$
}

1 Institute of Phytopathology, Christian-Albrechts-University Kiel, Hermann-Rodewald-Str. 9, D-24118, Kiel, Germany; E-Mail: javerreet@phytomed.uni-kiel.de

2 Botany and Microbiology Department, College of Science, King Saud University, P.O. Box: 2455, Riyadh 1145, Saudi Arabia; E-Mails: abhakali@ksu.edu.sa (A.H.B.); mbmoslem@ksu.edu.sa (M.M.)

3 Plant Pathology Research Institute, Agricultural Research Centre, Giza, Egypt

4 Laboratory of Phytopathology, Wageningen University, Droevendaalsesteeg 1, NL-6708 PB Wageningen, The Netherlands; E-Mail: pierre.dewit@wur.nl

* Author to whom correspondence should be addressed; E-Mail: kamel200@ksu.edu.sa; Tel.: +966-92-1467-580; Fax: +966-1467-5833.

Received: 2 December 2010; in revised form: 4 January 2011 / Accepted: 4 January 2011 / Published: 19 January 2011

\begin{abstract}
Early detection of infection is very important for efficient management of Mycosphaerella graminicola leaf blotch. To monitor and quantify the occurrence of this fungus during the growing season, a diagnostic method based on real-time PCR was developed. Standard and real-time PCR assays were developed using SYBR Green chemistry to quantify $M$. graminicola in vitro or in wheat samples. Microsatellite dinucleotide specific-primers were designed based on microsatellite repeats of sequences present in the genome of $M$. graminicola. Specificity was checked by analyzing DNA of 55 M. graminicola isolates obtained from different geographical origins. The method appears to be highly specific for detecting M. graminicola; no fluorescent signals were observed from 14 other closely related taxa. Primer (CT) $7 \mathrm{G}$ amplified a specific amplicon of $570 \mathrm{bp}$ from all M. graminicola isolates. The primers did not amplify DNA extracted from 14 other fungal species. The approximate melting temperature (Tm) of the (CT) $7 \mathrm{G}$ primer was $84.2{ }^{\circ} \mathrm{C}$. The detection limit of the real-time PCR assay with the primer sets (CT) $7 \mathrm{G}$ is $10 \mathrm{fg} / 25 \mu \mathrm{L}$, as compared to $10 \mathrm{pg} / 25 \mu \mathrm{L}$ using conventional PCR technology.
\end{abstract}


From symptomless leaves, a PCR fragment could be generated two days after inoculation. Both conventional and real-time PCR could successfully detect the fungus from artificially inoculated wheat leaves. However, real-time PCR appeared much more sensitive than conventional PCR. The developed quantitative real-time PCR method proved to be rapid, sensitive, specific, cost-effective and reliable for the identification and quantification of M. graminicola in wheat.

Keywords: Septoria tritici blotch; microsatellite; wheat; Dothidiomycete; molecular diagnostics

\section{Introduction}

Septoria tritici blotch (STB) of wheat (Triticum aestivum L.), caused by the fungal pathogen Mycosphaerella graminicola (anamorph: Septoria tritici), occurs in all wheat-growing areas world-wide, with an increasing economic impact over the last decades [1]. The causal agent, $S$. tritici, was first described by Desmazières [2]. Sanderson identified the ascomycete M. graminicola as the sexual stage (teleomorph) of $S$. tritici $[3,4]$. The origin of $M$. graminicola is most likely the Middle East [5]. M. graminicola is developing rapidly as a model for fungi in the order Dothideales [6,7]. Presently the fungus represents a major economic concern for global wheat production [8].

Polymerase chain reaction (PCR) methods that record fluorescence in real time when samples pass photo detection diodes have been described. This can be achieved by using double-stranded DNA-specific dyes, such as SYBR green (SG). The sensitivity of this method is similar or better than other PCR methods [2]. Recently, PCR-based real-time quantitative assays have been developed for the detection of a variety of plant pathogens [9-11], enabling high throughput diagnostics of plant pathogen infection in a relatively short time.

Specific PCR tests have been developed for identification of M. graminicola in wheat [12-15]. A PCR system in a fluorescent amplification-based specific hybridization (FLASH) format was developed for the detection and identification of M. graminicola [16]. Microsatellites and repeat sequence polymorphisms have been studied previously using real-time PCR chemistries such as hybridization probes [17,18]. Microsatellites have been used in several epidemiological studies of phytopathogenic fungi $[19,20]$.

Our reasoning for testing microsatellites as a diagnostic tool for M. graminicola is based on the unique characteristics of this class of markers. Microsatellites are short tandem repeats of a simple nucleotide sequence, inherited in a Mendelian fashion, and are evenly distributed in the genome. Although we could not test every potential non-target, our assumption is that microsatellites are usually species-specific [21,22]. Also, presymptomatic and accurate diagnosis of viable pathogen structures in infected wheat plants is desirable for determining latent periods of epidemics and for timely treatments with fungicides.

Conventional methods to detect and identify fungal pathogens in crop plants are time consuming, laborious, and require skilled taxonomical expertise [23,24]. Therefore, a PCR-based assay was developed with $M$. graminicola-specific primers designed on the repeat motif. The objective of this 
study was to develop a quantitative PCR (qPCR) assay based on the detection of the SYBR Green dye for the quantitative assessment of M. graminicola in wheat tissues.

\section{Experimental Section}

\subsection{Fungal Isolates and Growth Conditions}

Fifty-five isolates of $M$. graminicola and other fungal species used in the current study are listed in Table 1. Isolates used for DNA isolation were grown on yeast glucose broth (YG; 1\% yeast extract, $3 \%$ glucose) at $18{ }^{\circ} \mathrm{C}$ by shaking for five days on an orbital shaker at a speed of $120 \mathrm{rpm}$. Spores were collected from YG by centrifugation and washed three times with sterile water and subsequently once with $0.6 \mathrm{M} \mathrm{MgSO} 4$ (pH 5.8). For storage for three-to-six months, the M. graminicola isolates were cultured on Malt Yeast Agar (MYA) plates then stored at $4{ }^{\circ} \mathrm{C}$ or $-80{ }^{\circ} \mathrm{C}$ in $\mathrm{PD}$ broth medium supplemented with $10 \%$ glycerol [14].

Table 1. List of Mycosphaerella graminicola isolates and isolates of other fungal species used to evaluate the specificity of the primers developed for identification and detection of M. graminicola.

\begin{tabular}{|c|c|c|c|c|c|c|c|c|c|}
\hline $\begin{array}{l}\text { Isolate } \\
\text { Code }\end{array}$ & Fungal species & Host & Origin & $\begin{array}{c}\text { PCR } \\
\text { specificity }^{\mathrm{a}}\end{array}$ & $\begin{array}{l}\text { Isolate } \\
\text { Code }\end{array}$ & Fungal species & Host & Origin & $\begin{array}{c}\text { PCR } \\
\text { specificity }^{\mathrm{a}}\end{array}$ \\
\hline K-Or-1 & M. graminicola & Wheat & Germany & $\bullet$ & H-Ba-103 & M. graminicola & Wheat & Germany & $\bullet$ \\
\hline K-Or-30 & M. graminicola & Wheat & Germany & $\bullet$ & H-Ba-104 & M. graminicola & Wheat & Germany & $\bullet$ \\
\hline K-Or-38 & M. graminicola & Wheat & Germany & $\bullet$ & H-Ba-116 & M. graminicola & Wheat & Germany & $\bullet$ \\
\hline K-Or-44 & M. graminicola & Wheat & Germany & $\bullet$ & $\mathrm{CH} 1$ & M. graminicola & Wheat & Switzerland & $\bullet$ \\
\hline OK-102 & M. graminicola & Wheat & Germany & $\bullet$ & $\mathrm{CH} 2$ & M. graminicola & Wheat & Switzerland & $\bullet$ \\
\hline OK-108 & M. graminicola & Wheat & Germany & $\bullet$ & $\mathrm{CH} 3$ & M. graminicola & Wheat & Switzerland & $\bullet$ \\
\hline OK-109 & M. graminicola & Wheat & Germany & $\bullet$ & $\mathrm{CH} 4$ & M. graminicola & Wheat & Switzerland & - \\
\hline OK-112 & M. graminicola & Wheat & Germany & $\bullet$ & $\mathrm{CH} 5$ & M. graminicola & Wheat & Switzerland & $\bullet$ \\
\hline OK-120 & M. graminicola & Wheat & Germany & $\bullet$ & FCH1 & M. graminicola & Wheat & France & $\bullet$ \\
\hline $\mathrm{K}-\mathrm{Ba}-10$ & M. graminicola & Wheat & Germany & $\bullet$ & $\mathrm{FCH} 2$ & M. graminicola & Wheat & France & $\bullet$ \\
\hline $\mathrm{K}-\mathrm{Ba}-20$ & M. graminicola & Wheat & Germany & $\bullet$ & $\mathrm{FC} 1$ & M. graminicola & Wheat & France & $\bullet$ \\
\hline K-Ba-30 & M. graminicola & Wheat & Germany & $\bullet$ & $\mathrm{FC} 2$ & M. graminicola & Wheat & France & $\bullet$ \\
\hline $\mathrm{K}-\mathrm{Ba}-40$ & M. graminicola & Wheat & Germany & $\bullet$ & FN4 & M. graminicola & Wheat & France & $\bullet$ \\
\hline K-Ba-60 & M. graminicola & Wheat & Germany & $\bullet$ & FN5 & M. graminicola & Wheat & France & $\bullet$ \\
\hline G-Or-1 & M. graminicola & Wheat & Germany & $\bullet$ & GBW1 & M. graminicola & Wheat & England & $\bullet$ \\
\hline G-Or-6 & M. graminicola & Wheat & Germany & $\bullet$ & GBW2 & M. graminicola & Wheat & England & $\bullet$ \\
\hline G-Or-8 & M. graminicola & Wheat & Germany & $\bullet$ & GBE2 & M. graminicola & Wheat & England & $\bullet$ \\
\hline G-Or-88 & M. graminicola & Wheat & Germany & $\bullet$ & GBE4 & M. graminicola & Wheat & England & $\bullet$ \\
\hline G-or-98 & M. graminicola & Wheat & Germany & $\bullet$ & GBN1 & M. graminicola & Wheat & England & $\bullet$ \\
\hline G-Or-102 & M. graminicola & Wheat & Germany & $\bullet$ & GBN2 & M. graminicola & Wheat & England & $\bullet$ \\
\hline M-or-1 & M. graminicola & Wheat & Germany & $\bullet$ & FOV & $\begin{array}{c}\text { Fusarium oxysporum } \\
\text { f. sp. vasinfectum }\end{array}$ & Cotton & Egypt & ○ \\
\hline M-or-4 & M. graminicola & Wheat & Germany & $\bullet$ & FS & Fusarium solani & Cotton & Egypt & ○ \\
\hline M-Or-8 & M. graminicola & Wheat & Germany & $\bullet$ & FG & Fusarium germanium & Wheat & Germany & ० \\
\hline M-Or-82 & M. graminicola & Wheat & Germany & $\bullet$ & FP & Fusarium poae & Wheat & Germany & ० \\
\hline
\end{tabular}


Table 1. Cont.

\begin{tabular}{|c|c|c|c|c|c|c|c|c|c|}
\hline $\begin{array}{l}\text { Isolate } \\
\text { Code } \\
\end{array}$ & Fungal species & Host & Origin & $\begin{array}{c}\text { PCR } \\
\text { specificity }^{\text {a }} \\
\end{array}$ & $\begin{array}{l}\text { Isolate } \\
\text { Code } \\
\end{array}$ & Fungal species & Host & Origin & $\begin{array}{c}\text { PCR } \\
\text { specificity }^{\mathrm{a}} \\
\end{array}$ \\
\hline M-Or-98 & M. graminicola & Wheat & Germany & $\bullet$ & MP & $\begin{array}{c}\text { Macrophomina } \\
\text { phaseolina }\end{array}$ & Cotton & Egypt & ० \\
\hline M-or-102 & M. graminicola & Wheat & Germany & $\bullet$ & SP & Septoria passerinii & Barely & USA & ० \\
\hline L-Or-1 & M. graminicola & Wheat & Germany & $\bullet$ & $\mathrm{TH}$ & $\begin{array}{c}\text { Trichoderma } \\
\text { harzianum }\end{array}$ & Cotton & Egypt & ० \\
\hline L-Or-8 & M. graminicola & Wheat & Germany & $\bullet$ & $\mathrm{SN}$ & $\begin{array}{c}\text { Stagonospora } \\
\text { nodorum }\end{array}$ & Wheat & Germany & ० \\
\hline L-Or-84 & M. graminicola & Wheat & Germany & $\bullet$ & $\mathrm{PT}$ & Pyernophora teres & Wheat & Germany & 0 \\
\hline L-Ba-1 & M. graminicola & Wheat & Germany & $\bullet$ & PTR & $\begin{array}{l}\text { Pyernophora } \\
\text { tritici-repentis } \\
\end{array}$ & Wheat & Germany & o \\
\hline L-Ba-8 & M. graminicola & Wheat & Germany & $\bullet$ & $\mathrm{PH}$ & $\begin{array}{c}\text { Pseduosercosporella } \\
\text { heropotrichoides }\end{array}$ & Wheat & Germany & ० \\
\hline L-Ba-110 & M. graminicola & Wheat & Germany & $\bullet$ & Pen & Pencillium sp. & Unknown & Egypt & ० \\
\hline H-Or-1 & M. graminicola & Wheat & Germany & $\bullet$ & Alt & Alternaria sp. & Unknown & Egypt & ○ \\
\hline H-Or-8 & M. graminicola & Wheat & Germany & $\bullet$ & $\mathrm{CB}$ & Cercospora beticola & Suger beet & Germany & $\circ$ \\
\hline H-Or-90 & M. graminicola & Wheat & Germany & $\bullet$ & & & & & \\
\hline
\end{tabular}

${ }^{\mathrm{a}}$ The presence or absence of species-specific amplicon is indicated by a positive $(\bullet)$ or negative $(\circ)$ for each set of primers.

\subsection{Artificial Inoculation of Wheat Plants and DNA Isolation}

Seeds of cultivar Ritmo (a highly susceptible wheat cultivar) were germinated on filter paper in the dark at $25{ }^{\circ} \mathrm{C}$. After $24 \mathrm{~h}$, the seeds were placed at $5{ }^{\circ} \mathrm{C}$ for $48 \mathrm{~h}$ followed by incubation at $25{ }^{\circ} \mathrm{C}$ for $24 \mathrm{~h}$. The plants were then transferred to a growth chamber at $19{ }^{\circ} \mathrm{C}$, with a day/night regime of $16 \mathrm{~h} / 8 \mathrm{~h}$. Wheat seedlings were inoculated by placing $10 \mu \mathrm{L}$ of $M$. graminicola pycnidiospore suspension (containing $10^{6}$ spores) on each emerged leaf (leaf 2). Control plants were treated with distilled water. The inoculated plants were kept in a mist chamber for $72 \mathrm{~h}$ and then returned to the growth chamber at $21{ }^{\circ} \mathrm{C}$ (day) $/ 16{ }^{\circ} \mathrm{C}$ (night) temperatures with a day/night regime of $16 \mathrm{~h} / 8 \mathrm{~h}$. Samples for PCR analysis were collected at $0,2,6,8,10,12,14,16,18$ and 20 days after inoculation. DNA was extracted from wheat leaves according to procedures described by Guo et al. [15].

\subsection{DNA Isolation}

A modification of the traditional sodium dodecyl sulfate (SDS) extraction procedure was adopted [1]. Fungal mats (100 mg) were harvested and homogenized in $400 \mu \mathrm{L}$ of sterile salt homogenizing buffer (200 mM Tris-HCl, $\mathrm{pH} 8.5,250 \mathrm{mM} \mathrm{NaCl}, 25 \mathrm{mM}$ EDTA, 0.5\% SDS). Then, $6 \mu \mathrm{L}$ of RNase A (final concentration $20 \mathrm{mg} \mathrm{mL}^{-1}$ ) was added and mixed. The samples were incubated at $65^{\circ} \mathrm{C}$ for $10 \mathrm{~min}$, after which $130 \mu \mathrm{L}$ of $3 \mathrm{M}$ sodium acetate, $\mathrm{pH} 5.2$, was added to each sample. Samples were mixed in a Vortex for $30 \mathrm{~s}$ at maximum speed, and incubated at $-20{ }^{\circ} \mathrm{C}$ for $10 \mathrm{~min}$. The lysate was centrifuged at $13,000 \mathrm{rpm}$ at $4{ }^{\circ} \mathrm{C}$ for $15 \mathrm{~min}$. The supernatant was transferred to fresh tubes. An equal volume of isopropanol was added to each sample, mixed, and samples were incubated at $-20{ }^{\circ} \mathrm{C}$ for $10 \mathrm{~min}$. Samples were then centrifuged for $20 \mathrm{~min}$ at $4{ }^{\circ} \mathrm{C}$, at $6,000 \mathrm{rpm}$. DNA pellets 
were washed twice with $700 \mu \mathrm{L}$ of washing solution (100\% and $70 \%$ ethanol, respectively). The DNA pellets were subsequently air-dried in an oven at $40{ }^{\circ} \mathrm{C}$ for at least $10 \mathrm{~min}$. The resultant DNA pellet was then resuspended in $100 \mu \mathrm{L}$ of $1 \times$ TE (10 mM Tris-HCl, 1 mM EDTA) buffer, pH 8.0.

\subsection{Microsatellite Selection and Design of PCR Primers}

Microsatellites of varying length and type (di or trinucleotide) were selected from those identified by Karaoglu et al. [25], which are listed at http://www.mmrl.med.usyd.edu.au/an_contig.html. Microsatellite dinucleotide specific-primers were designed [(CTC TCT CTC TCT CT) G] based on microsatellite repeat sequence selected from the finished genome sequence of isolate IPO323 of M. graminicola (http://genome.jgi-psf.org/Mycgr3/Mycgr3.home.html).

\subsection{Microsatellite-Primed PCR (MSP-PCR)}

PCR mixtures contained $2 \mathrm{mM}$ deoxynucleoside triphosphates, 10 pmol concentrations of primer; $0.2 \mathrm{U}$ of Taq polymerase (Biolab, England), $1 \times$ buffer (Promega, Mannheim, Germany), $1.5 \mathrm{mM}$ $\mathrm{MgCl}_{2}$ and $50 \mathrm{ng}$ of template DNA in a total volume of $25 \mu \mathrm{L}$. The reactions were carried out in a PTC-200 Thermocycler (MJ Research, Waltham, USA) as follows: 1 cycle of 2 min at $94{ }^{\circ} \mathrm{C}$ followed by 40 cycles of denaturation at $94{ }^{\circ} \mathrm{C}$ for $1 \mathrm{~min}$, annealing at $55^{\circ} \mathrm{C}$ for $90 \mathrm{~s}$ and extension at $72{ }^{\circ} \mathrm{C}$ for $2 \mathrm{~min}$. The thermal profile ended with a final extension at $72{ }^{\circ} \mathrm{C}$ for $7 \mathrm{~min}$. All PCR amplification products were analyzed by agarose gel (1.5\%) electrophoresis [26].

\subsection{Light Cycler PCR (LC-PCR)}

Real-time PCR reactions were carried out with a LightCycler instrument using the QuantiTect ${ }^{\mathrm{TM}}$ SYBR $^{\circledR}$ Green PCR Kit (Qiagen, Hilden, Germany) with $0.3 \mu \mathrm{M}$ of each primer, $5 \mathrm{mM} \mathrm{MgCl} 2$ and $5 \mu \mathrm{L}$ of DNA template. DNA was replaced by sterile water in the negative control. The program used for real time PCR was $10 \mathrm{~min}$ at $95{ }^{\circ} \mathrm{C}$, followed by 35 cycles of $15 \mathrm{~s}$ denaturation at $95{ }^{\circ} \mathrm{C}, 30 \mathrm{~s}$ annealing at $60{ }^{\circ} \mathrm{C}, 30 \mathrm{~s}$ elongation at $72{ }^{\circ} \mathrm{C}$. Samples were placed into a glass capillary, capped, centrifuged for a few seconds in a micro-centrifuge using appropriate adapters, and then placed into the LightCycler rotor. In addition, the PCR products were recovered from the capillaries and analyzed by agarose gel $(1.5 \%)$ electrophoresis and stained with ethidium bromide [27].

\subsection{Specificities and Sensitivities of PCR Amplifications}

The specificities of the gene-specific primers designed in this study were tested in PCR amplifications using purified genomic DNA from various fungal species as template. To assess the sensitivity of the detection of $M$. graminicola using the designed primers, DNA dilution series containing $10 \mathrm{ng}$ to $50 \mathrm{fg}$ of DNA from selected isolates were subjected to conventional, and real-time PCR analyses, respectively. 


\section{Results}

\subsection{Specificity and Sensitivity of the PCR Assays}

The specificity of the real-time PCR assay was tested with template DNA extracted from the 55 isolates of M. graminicola and other fungal species that are listed in Table 1. Dinucleotide specific-primer amplified a single fragment from total genomic DNA of $M$. graminicola (Figure 1) and its inoculated leaves. There was no amplification obtained in healthy plants (HP) or the other fungal pathogens tested (Stagonospora nodorum (SN), Pseudocercosporella herpotrichoides (PT)) (Figure 2). The (CT) $7 \mathrm{G}$ primer amplified a unique DNA fragment of approximately 570 bp from M. graminicola, whereas no amplification was achieved with DNA isolated from other fungal species. Using DNA extracted from M. graminicola cultures, the detection limit was $100 \mathrm{pg} / \mu \mathrm{L}$ with conventional PCR, whereas the detection limit was $50 \mathrm{fg} / \mu \mathrm{L}$ by real-time PCR, thus the real-time PCR assay was 20-fold more sensitive than conventional PCR (Figure 3).

Figure 1. Polymerase chain reaction (PCR) amplification of genomic DNA isolated from 55 isolates of $M$. graminicola using primer pair (CT) C9 showing a amplification product of 570 bp. Lane M, 100 bp DNA marker; arrows indicate the 1000 and 500 bp DNA marker.

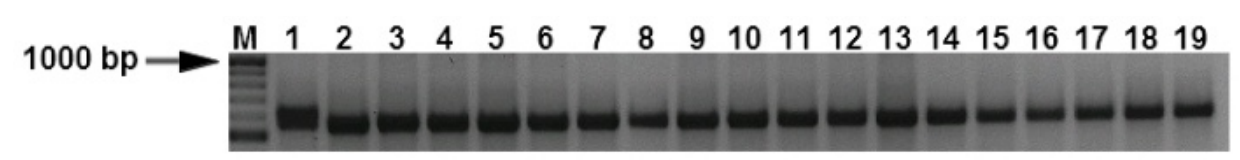

$\begin{array}{lllllllllllllllllll}20 & 21 & 22 & 23 & 24 & 25 & 26 & 27 & 28 & 29 & 30 & 31 & 32 & 33 & 34 & 35 & 36 & 37 & 38\end{array}$
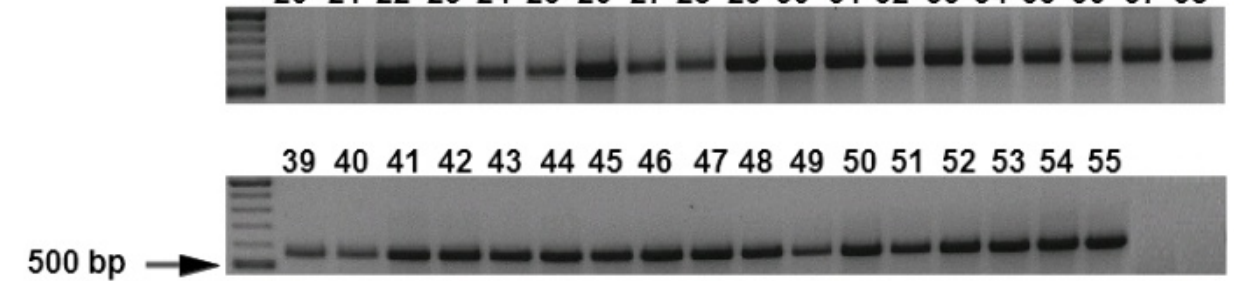

Figure 2. Polymerase chain reaction (PCR) amplification performed to assess specificity of the primer pair (CT) C9. A PCR fragment of $570 \mathrm{bp}$ could only be amplified from Lanes 1-8 of genomic DNA from different isolates of Mycosphaerella graminicola, lane 9, DNA from Stagonospora nodorum (SN), lane 10, DNA from Pseudocercosporella herpotrichoides (PT), lane 11, healthy plant (HP), and lane 12-13, plants infected by M. graminicola (IP1 and IP2). Lane M, 100 bp DNA marker.

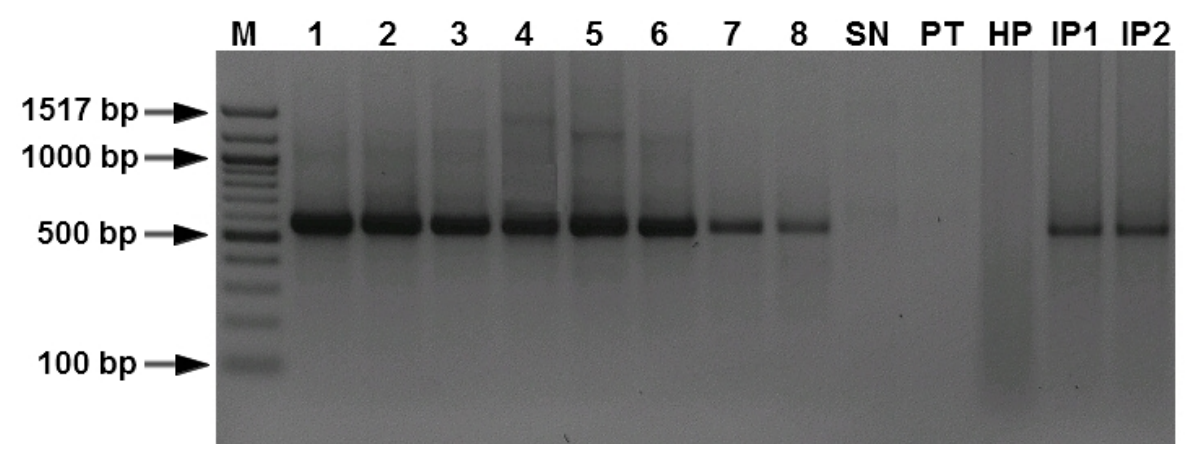


Figure 3. Comparison of the sensitivity of conventional (A) and real-time PCR (B), using different concentrations of Mycosphaerella graminicola DNA. For both (A) and (B), Lane 1, $10 \mathrm{ng}$; lane 2, $1 \mathrm{ng}$; lane 3, $100 \mathrm{pg}$; lane 4, $10 \mathrm{pg}$; lane 5,1 pg; lane 6, $100 \mathrm{fg}$; lane 7, 50 fg. Lane M, 100 bp DNA marker.

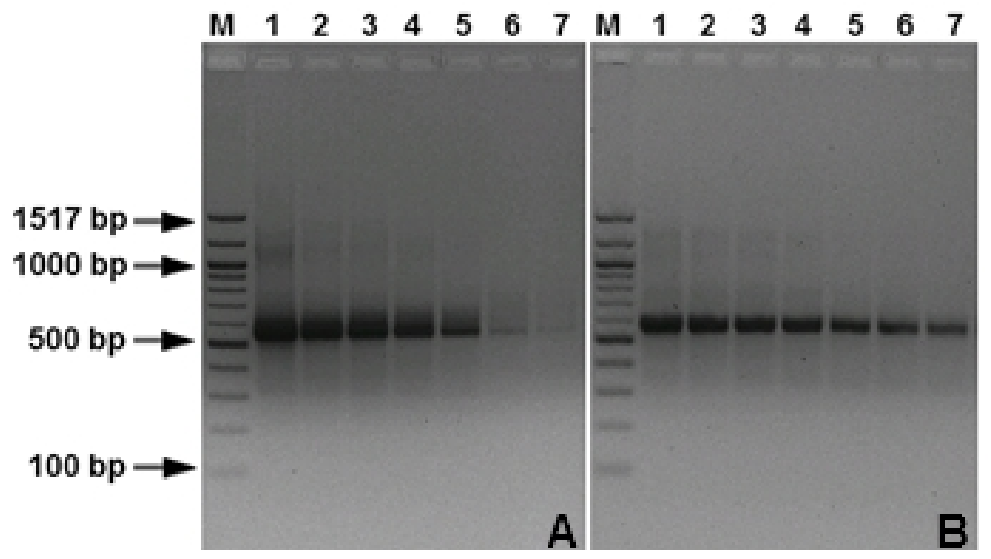

\subsection{Melt Curve Analysis}

In the assay, SYBR Green I was used as the fluorescent dye enabling real-time detection of PCR products. Characterization of the amplicons was achieved by melting point analysis $84 \pm 0.2{ }^{\circ} \mathrm{C}$. Nonspecific products such as primer dimers could readily be distinguished from PCR products by their lower melting points. PCR reactions performed on $50 \mathrm{ng}$ of $M$. graminicola DNA with primers targeted at fungal sequences led to similar $C t$ and dissociation curves compared to a control devoid of DNA matrix, showing the specificity of fungal quantification (Figure 2). The system enables a 35-cycle PCR with 35 samples to be completed in $45 \mathrm{~min}$, including quantification and identification of the product. Typical results from the probe melt curve analysis are shown in Figure 4. All products were subjected to analytical gel electrophoresis to confirm the $570 \mathrm{bp}$ amplicon size.

Figure 4. Amplification plot of fungal DNA from Mycosphaerella graminicola and other fungal species, as well as in symptomless wheat tissue and a non-template negative control by using a LightCycler instrument and (CT) C9 primer pair.

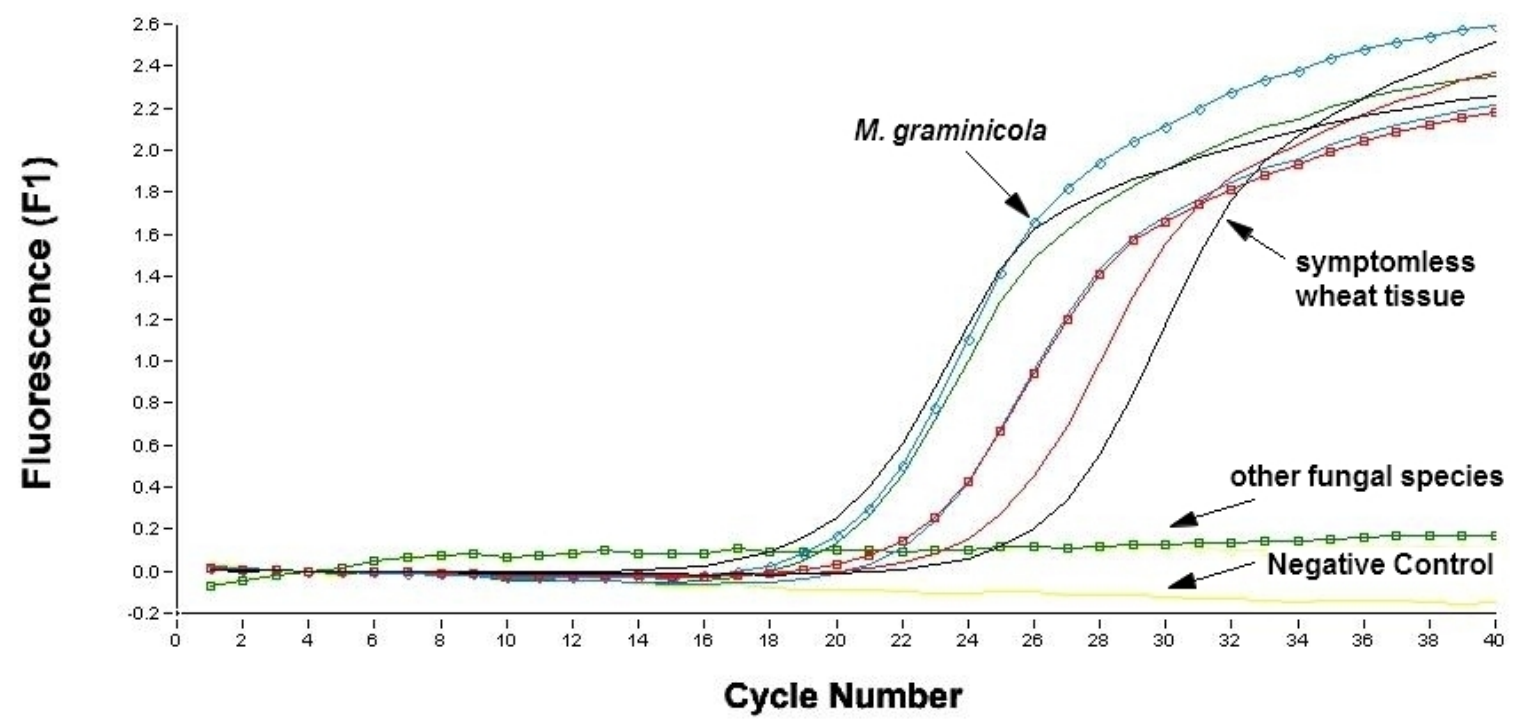




\subsection{Quantification of M. graminicola in Infected Plants}

Artificially M. graminicola-inoculated asymptomatic wheat leaves were collected and fungal DNA was detected with conventional PCR and real-time PCR 0, 2, 6, 8, 10, 12, 14, 16, 18 and 20 days post inoculation. Inoculated wheat leaves showed the 750-bp fragment that is diagnostic for M. graminicola infections after PCR with dinucleotide specific primers. No PCR products were generated with DNA isolated from Fusarium graminearum-inoculated or Pseudocercosporella herpotrichoides-inoculated wheat plants or from DNA isolated from healthy wheat tissue. A clear single DNA fragment was amplified from the samples taken on day $0,2,6,8,10,12,14,16,18$ and 20 after inoculation (Figure 5, lanes 1-10). From inoculated wheat leaves harvested at day 0, although thoroughly washed with water prior to PCR, a clear fragment was still present representing the inoculated fungus. The intensity of the amplified DNA fragment increased significantly at 10 days after inoculation. Between 10 and 20 days after inoculation, the intensity of the amplified fragment increased more than five-fold. As mentioned before, the dinucleotide-specific primers can detect the pathogen from 10 pg of DNA isolated from infected leaf tissue in conventional PCR assays and from $50 \mathrm{fg}$ in real-time PCR assays; the higher sensitivity offered by the real-time PCR assay makes it more reliable for detecting the fungus during the latent stage of infection. The sensitivity of the method would allow the quantification of fungal growth in different plant tissues during the progress of infection.

Figure 5. Polymerase chain reaction amplification performed to diagnose Mycosphaerella graminicola in artificially inoculated wheat leaves by (CT) C9 primer pair (product $570 \mathrm{bp}$ ). Lanes 1 to 10, DNA from inoculated leaves sampled at 0, 2, 6, 8, 10, 12, 14, 16, 18 and 20 days post inoculation with M. graminicola; lanes 11-12, DNA from healthy plants; lane 13, DNA from leaves inoculated with Pseudocercosporella herpotrichoides; lane 14, leaves inoculated d with Fusarium graminearum. Lane M, 100 bp DNA marker.

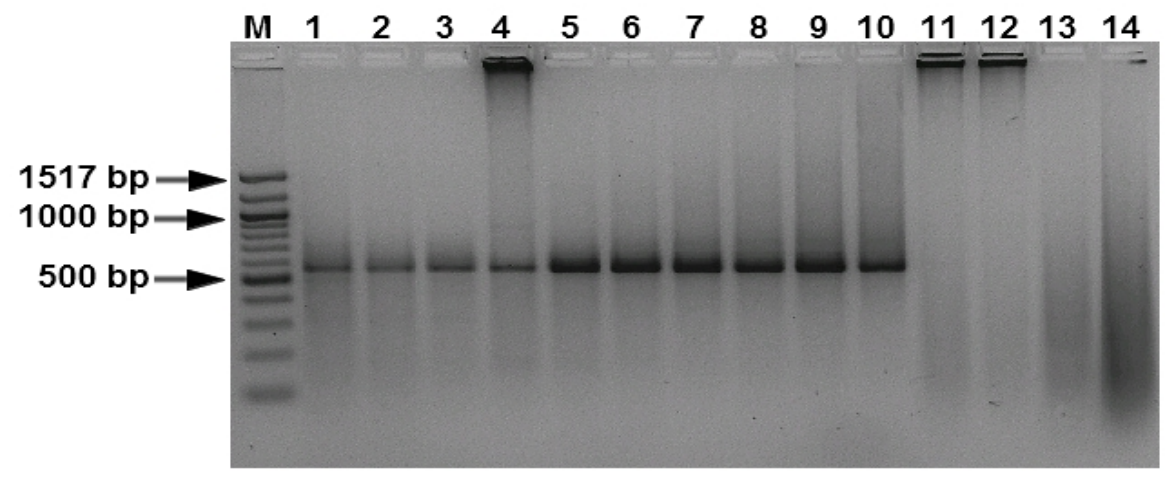

\section{Discussion}

Microsatellites have been used as genetic markers in numerous DNA and PCR fingerprinting trials for strain typing of a variety of filamentous fungi and yeasts without prior knowledge of their abundance and distribution in the investigated fungal genomes [21,28,29]. Here, we describe the use of conventional and real-time PCR using fluorescent SYBR Green I dye to quantify M. graminicola present in wheat tissue. 
The SYBR Green dye has no sequence specificity and therefore does not require the design of specific fragments complementary to the target DNA. It can be used to detect any double-stranded (ds) DNA PCR product [30]. In the current research, positive amplification was conducted under a melting temperature of $84{ }^{\circ} \mathrm{C}$. Therefore, non-specific amplification and primer dimers could easily be distinguished from the authentic amplicon pool. The values of the cycle threshold $(\mathrm{Ct})$ linearly correlated with the concentration of the target DNA, indicating that the method is suitable for qualitative and quantitative assay.

Specific dinucleotide primers amplified a single PCR fragment of $570 \mathrm{bp}$ specific for isolates of M. graminicola, but no fragment was generated from 14 other fungal species belonging to 13 different genera. The primers amplified similar-sized fragments from fungus culture grown in vitro and wheat leaves inoculated with $M$. graminicola. This primer pairs allowed a reliable DNA quantification at concentrations as low as $50 \mathrm{fg}$, which is very sensitive, as reported by other researchers $[12,14,15]$. Real-time PCR was found to be more sensitive than the standard amplification procedure, and a successful amplification was obtained with M. graminicola DNA. Dinucleotide and trinucleotide repeats have higher probabilities of polymorphism than mononucleotide repeats [31]. The visual diagnostics of disease is difficult due to the presence of different Mycosphaerella species within one field and even on one plant, and the difficulty in distinguishing symptoms caused by biotic and abiotic stress. Identification of Mycosphaerella species based on morphology and presence of fruiting bodies and conidia is difficult due to the considerable morphological similarity of this fungus with other closely related fungi [16].

Here we compared conventional PCR and real-time PCR assays, which enabled us to detect the pathogen on asymptomatic plants collected two days after artificial inoculation. It has also been shown that this assay can be used to monitor fungal development in wheat tissue during the course of infection, even the starting inoculum could be detected immediately after washing of the inoculated leaves.

Fraaije et al. [12] did not detect an exponential increase in biomass until 14 days post inoculation using the PCR/PicoGreen assay. In our case using SYBR Green, we observed a significant increase at 10 days after inoculation. Real-time PCR was more sensitive than conventional PCR and can be used for routine quantitative analysis of $M$. graminicola in wheat tissue to trace new infections. This will be especially important when the target DNA concentration is low or PCR inhibitory substances are present [32].

Biomass accumulation of avirulent isolates of $M$. graminicola on resistant hosts could also be assessed by TaqMan ${ }^{\circledR}$ quantitative PCR using mating-type-specific probe and primer combinations, and results showed that the biomass of avirulent isolates on resistant host species and cultivars was either maintained or increased over time [33].

Accurate, rapid, and early detection of $M$. graminicola on wheat will assist the development of sustainable disease control and management.

\section{Acknowledgements}

This work was partially conducted by K.A. Abd-Elsalam while working as a postdoctoral researcher at the Christian-Albrechts-University Kiel. The authors acknowledge the assistance of Guo 
JR for providing the genomic DNA from infected and healthy plants. Also, this study was supported in part by grants from the National Plan of Science and Technology, King Abdulaziz City of Science and Technology, Riyadh, Saudi Arabia (10-Bio-971-02). A.A. Aly is gratefully acknowledged for stimulating discussions and for critically reading the manuscript.

\section{References}

1. Eyal, Z. The Septoria tritici and Stagonospora nodorum blotch diseases of wheat. Eur. J. Plant Pathol. 1999, 105, 629-641.

2. Desmazières, J.B.H.J. Cryptogames nouvelles. Ann. Sci. Nat. 1842, 17, 91-118.

3. Sanderson, F.R. A Mycosphaerella species as the ascogenous state of Septoria tritici Rob. and Desm. NZ J. Bot. 1972, 10, 707-709.

4. Sanderson, F.R. Mycosphaerella graminicola (Fuckel) Sand-erson comb. nov., the ascogenous state of Septoria tritici Rob. and Desm. NZ J. Bot. 1976, 14, 359-360.

5. Halama, P. The occurrence of Mycosphaerella graminicola, teleomorph of Septoria tritici in France. Plant Pathol. 1996, 45,135-138.

6. Aptroot, A. CBS Biodiversity Series 5: Mycosphaerella and its anamorphs: 2. Conspectus of Mycosphaerella; Centraalbureau voor Schimmelcultures: Utrecht, The Netherlands, 2006.

7. Goodwin, S.B. Minimum phylogenetic coverage: An additional criterion to guide the selection of microbial pathogens for initial genomic sequencing efforts. Phytopathology 2004, 94, 800-804.

8. Arraiano, L.S.; Chartrain, L.; Bossolini, E.; Slatter, H.N.; Keller, B.; Brown, J.K.M. A gene in European wheat cultivars for resistance to an African isolate of Mycosphaerella graminicola. Plant Pathol. 2007, 56, 73-78.

9. Abd-Elsalam, K.A.; Bahkali, H.A.; Al-Khedhairy, A.A.; Verreet, J.-A. Development of a conventional and Lightcycler PCR assay for detection of Fusarium solani. Gene Genomes Genomics 2008, 2, 63-67.

10. de Weerdt, M.; Zijlstra, C., van Brouwershaven, I.R.; van Leeuwen, G.C.M.; de Gruyter J.; Kox, L.F.F. Molecular detection of Fusarium foetens in Begonia. J. Phytopathol. 2006, 154, 694-700.

11. Francois, C.; Castagnone, C.; Boonham, N.; Tomlinson, J.; Lawson, R.; Hockland, S.; Quill, J.; Vieira, P.; Mota, M.; Castagnone-Sereno, P. Satellite DNA as a target for TaqMan real-time PCR detection of the pinewood nematode, Bursaphelenchus xylophilus. Mol. Plant Pathol. 2007, 8, 803-809.

12. Fraaije, B.A.; Lovell, D.J., Rohel, E.A.; Hollomon, D.W. Rapid detection and diagnosis of Septoria tritici epidemics in wheat using a polymerase chain reaction/PicoGreen assay. J. Appl. Microbiol. 1999, 86, 701-708.

13. Fraaije, B.A.; Lovell, D.J.; Coelho, J.M.; Baldwin, S.; Hollomon, D.W. PCR based assays to assess wheat varietal resistance to blotch (Septoria tritici and Stagonospora nodorum) and rust (Puccinia striiformis and Puccinia recondita) diseases. Eur. J. Plant Pathol. 2001, 107, 905-917.

14. Guo, J.R.; Schnieder, F.; Beyer, M.; Verreet, J.-A. Rapid detection of Mycosphaerella graminicola in wheat using reverse transcription-PCR assay. J. Phytopathol. 2005, 153, 674-679. 
15. Guo, J.R.; Schnieder, F.; Verreet, J.-A. Presymptomatic and quantitative detection of Mycospaerella graminicola development in wheat using real-time PCR. FEMS Microbiol. Lett. 2006, 262, 223-229.

16. Abramova, S.L., Ryazantsev, D.Y.; Voinova, T.M.; Zavriev, S.K. Diagnostics of phytopathogen fungi Septoria tritici and Stagonospora nodorum by fluorescent amplification-based specific hybridization (FLASH) PCR. Russ. J. Bioorg. Chem. 2007, 34, 97-102.

17. Dietmaier, W.; Hofstädter, F. Detection of microsatellite instability by real time PCR and hybridization probe melting point analysis. Lab. Invest. 2001, 81, 1453-1456.

18. von Ahsen, N.; Oellerich, M.; Schütz, E. DNA base bulge vs unmatched end formation in probebased diagnostic insertion/deletion genotyping: Genotyping the UGT1A1 (TA) polymorphism by real-time fluorescence PCR. Clin. Chem. 2000, 46, 1939-1945.

19. Guerin, F.; Gladieux, P.; Le Cam, B. Origin and colonization history of newly virulent strains of the phytopathogenic fungus Venturia inaequalis. Fungal. Genet. Biol. 2007, 44, 284-292.

20. Raboin, L.M.; Selvi, A.; Oliveira, K.M.; F. Paulet.; Calatayud, C.; Zapater, M.-F.; Brottier, P.; Luzaran, R.; Garsmeur, O.; Carlier, J.; D’Hont, A. Evidence for the dispersal of a unique lineage from Asia to America and Africa in the sugarcane fungal pathogen Ustilago scitaminea. Eur. J. Plant Pathol. 2007, 44, 64-76.

21. Selkoe, K.A. Toonen, R.J. Microsatellites for ecologists: A practical guide to using and evaluating microsatellite markers. Ecol. Lett. 2006, 9, 615-629.

22. Zane, L., Bargelloni, L.; Patarnello, T. Strategies for microsatellite isolation: A review. Mol. Ecol. 2002, 11, 1-16.

23. Lievens, B.; Grauwet, T.J.M.A.; Cammue, B.P.A.; Thomma, B.P.H.J. Recent developments in diagnostics of plant pathogens: A review. Recent Res. Develop. Microbiol. 2005, 9, 57-79.

24. McCartney, H.A.; Foster, S.J.; Fraaije, B.A.; Ward, E. Molecular diagnostics for fungal plant pathogens. Pest Manag. Sci. 2003, 59, 129-142.

25. Karaoglu, H.; Lee, C.M.Y.; Meyer, W. Survey of simple sequence repeats in completed fungal genomes. Mol. Biol. Evol. 2005, 22, 639-649.

26. Abd-Elsalam, K.A.; Asran-Amal, A.; El-Samawaty, A. Isolation of high quality DNA from cotton and its fungal pathogens. J. Plant Dis. Prot 2007, 114, 113-116.

27. Abd-Elsalam, K.A.; Guo, J.-R.; Moslem, M.A.; Bahkali, A.H.; Verreet, J.-A. Suitability of intergenic spacer or internal transcribed spacer microsatellite-primed PCR for the identification of phytopathogenic fungi. J. Rapid Autom. Methods Microbiol. 2009, 17, 383-397.

28. Chadha, S.; Gopalakrishna, T. Retrotransposon-microsatellite amplified polymorphism (REMAP) markers for genetic diversity assessment of the rice blast pathogen (Magnaporthe grisea). Genome 2005, 48, 943-945.

29. Meyer, W.; Castaneda, A.; Jackson, S.; Huynh, M.; Castaneda, E. Molecular typing of Ibero American Cryptococcus neoformans isolates, and the IberoAmerican Cryptococcal study group. Emerg. Infect. Dis. 2003, 9, 189-195.

30. Giglio, S.; Monis, P.T.; Saint, C.P. Legionella confirmation using real-time PCR and SYTO9 is an alternative to current methodology. Appl. Environ. Microbiol. 2005, 71, 8944-8948.

31. Christians, J.K.; Watt, C.A. Nucleotide repeats represent an important source of polymorphic microsatellite markers in Aspergillus nidulans. Mol. Ecol. Res. 2009, 9, 572-578. 
32. Ware, S.B. Aspects of sexual reproduction in Mycosphaerella species on wheat and barley genetic studies on specificity, mapping, and fungicide resistance. $\mathrm{PhD}$ thesis Wageningen University, The Netherlands, 2006.

33. Rudd, J.; Antoniw, J.; Marshall, J.; Motteram, R.; Fraaije, B.; Hammond-Kosack, K. Identification and characterisation Mycosphaerella graminicola secreted or surface-associated proteins with variable intragenic coding repeats. Fungal. Genet. Biol. 2010, 47, 19-32.

(C) 2011 by the authors; licensee MDPI, Basel, Switzerland. This article is an open access article distributed under the terms and conditions of the Creative Commons Attribution license (http://creativecommons.org/licenses/by/3.0/). 